\title{
RARE ROMAN FINDS FROM A GERMANIC (QUADI) SETTLEMENT: LUXURIOUS DESIRES OR RAW MATERIALS? \\ New research at the Ipolytölgyes-TSz-major site
}

\author{
Eszter Soós ${ }^{1}$ - Lajos Juhász ${ }^{2}$ - Hella Mag ${ }^{3}$ - Róbert Molnár ${ }^{4}$ \\ Hungarian Archaeology Vol. 9 (2020), Issue 2, pp. 29-37, https://doi.org/10.36338/ha.2020.2.2
}

During the Roman period, Germanic (Quadi) population settled in the valley of the Ipoly River. The locations of their sites are known thanks to earlier topographical research; however, a detailed evaluation of excavated archaeological assemblages has not been accomplished until recently. Since 2017, we conducted new archaeological investigations at the Ipolytölgyes-TSz-major site. Based on finds recovered from excavations and non-destructive surveys, we were able to draw a picture of the communities settling in the border zone of Pannonia in a more nuanced manner than ever before.

\section{INTRODUCTION}

Germanic (Quadi) population settled in the valley of the Ipoly River during the Roman period. Between the 1 st and the end of the 4th century AD, the Quadi population inhabited the western parts of present-day Slovakia; however, the available data suggest that it was only after the Marcomannnic Wars (166-180 AD) that they moved across the Garam River and settled also in modern-day Hungary. Their characteristic ceramic finds turn up even around the area of Miskolc. Contrasting the results of Slovakian research, however, there is a relative absence of published site reports in Hungary (Soós \& TANKó, 2018, 291-296). The network of settlements in the Ipoly valley is well-known, thanks to topographic surveys (MRT 1993), however, the evaluation of documented archaeological excavations has not been accomplished yet.

In spring 2017, members of the Tragor Ignác Museum in Vác conducted archaeological surveys at the site of Ipolytölgyes-TSz-major - contracted by the proprietor, MONO-Ipolyfabrik Ltd. In addition to Prehistoric features, parts of a Roman period (Germanic) building were brought to light, whose construction technique (with six posts) was identical to another building recovered there in the 1960s by István Erdélyi. Both buildings represent the most frequent type in the region where the Quadi settled (ERDÉLYI \& LAMIOVÁ-SChmiedlová, 1971). In order to assess the finds from 2017, it became necessary to evaluate earlier research, which, however, remained only partially published. This way, we were able to comparatively evaluate the ceramic assemblages from Ipolytölgyes and the characteristic finds from the Western Slovakian core area of Quadi settlements.

In the southwestern section of our site, excavation was not possible anymore; along the east side of the road between Szob and Parassapuszta, however, we were able to carry out systematic survey and also a metal detecting survey, in which volunteers cooperating with the Museum were also involved. This cooperation with civil volunteers started in 2017 and has become increasingly institutionalized since then: it is now also being facilitated by introducing the details of archaeological fieldwork to the participants in the form of lectures. The community archaeology program of the Ferenczy Museum Centre in Szentendre is an example to follow, as well as the activities organized by the Association for Community Archaeology, founded in 2019 (RÁCZ, 2017; 2019).

Hereby, it is also important to note the expertise of István Kóka, our museum collection assistant, with more than a decade-long experience in site detection and research, whose focus on the area of the Börzsöny

University of Pécs, Faculty of Humanities, Department of Archaeology. E-mail: soos.eszter@pte.hu

2 Eötvös Loránd University, Faculty of Humanities, Institute of Archaeological Sciences, Department of Antiquity. E-mail: juhasz.lajos@,btk.elte.hu

3 Tragor Ignác Museum, Vác. E-mail: mag.hella@muzeumvac.hu

4 E-mail: robert.molnar87@gmail.com 
Mountain also enriched our knowledge in regard to several new archaeological sites and other data. We would like to express our gratitude to archaeologists Klára Kővári and János Jakucs, archaeology student Márk Kékesi, museum collection assistant István Kóka, as well as to volunteers Ferenc Bartos, Attila Gulyás, Béla Konecsni, Attila Petyánszki and Gábor Szijjártó, for their help in the fieldwork.

\section{RESEARCH HISTORY}

The site of Ipolytölgyes-TSz-major is situated to the east from the Ipoly River and to the north from the Cserge (Ganádi-) Stream, on the western and southern slopes of a hill (Fig. 1). In 1967, a small-scale excavation took place here, organized by the Institute of Archaeology of the Hungarian Academy of Sciences, in result of which short reports and an article in Slovakian were published that drew conclusions only based on some distinguished objects (ERDÉLYI \& LAMIOvÁ-Schmiedlové, 1971). During the 1970s and 1980s, field surveys determined the full extent of this multi-period site (MRT 1993, 116, 10/1. lh). In February 2001, Klára Kővári conducted a small-scale excavation in the southeastern part of the industrial facility under construction, where she unearthed Middle Neolithic finds.

In 2017, the MONO-Ipolyfabrik Ltd. began to expand its facility. Regrettably, this was reported to the museum only subsequently, thus, when archaeological monitoring began, there was an approximately $1000 \mathrm{~m}^{2}$ large area in the southwest part of the site, already excavated to several meters' depth.

Archaeological investigations began in three different locations. To the north from the facility, in the area of the parking lot (Fig. 2/1), we were able to document features only on the surface - as they were blanketed later on. Traces of a Middle Neolithic settlement turned up there, in addition to a few Copper Age and Bronze Age features. In the waste storage area (Fig. 2/2), a small number of Bronze

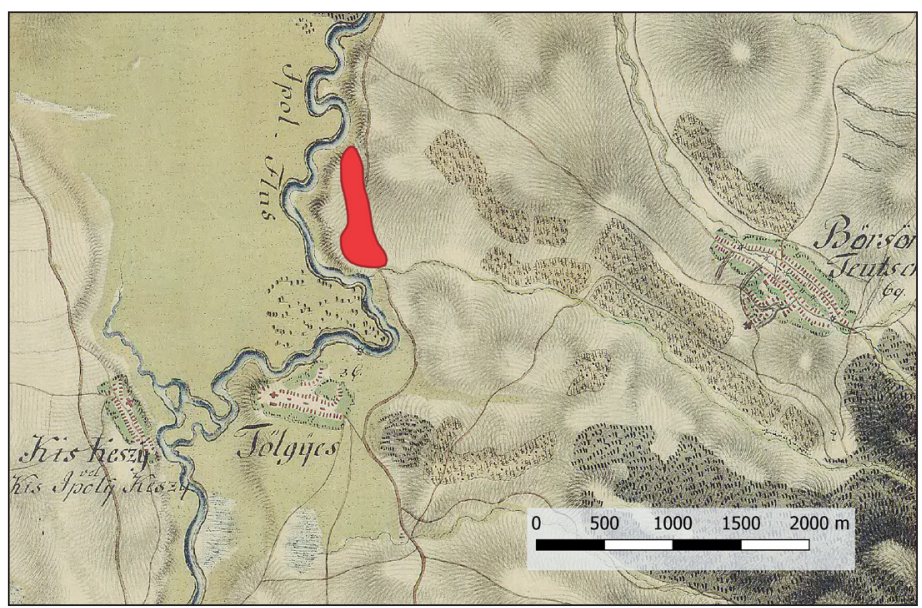

Fig. 1. The site of Ipolytölgyes-TSz-major on the map of the First Military Survey

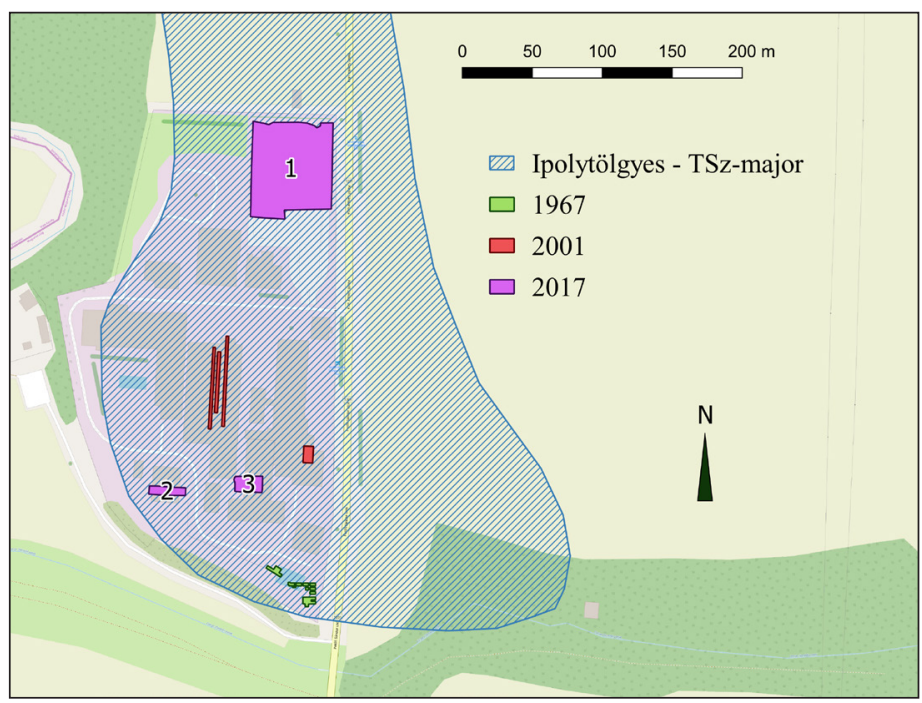

Fig. 2. The southern perimeters of the site and the area of excavation Age features were found. During the construction of the industrial hall (Fig. 2/3), the southeast corner of a Roman period building, and Copper and Bronze Age settlement features were identified. Based on the intensity of the archaeology, it is likely that the (unauthorized) excavation of the $1000 \mathrm{~m}^{2}$ large area in the south section of the site resulted in a significant loss of data.

\section{RESULTS OF THE FIELD-SURVEY}

In addition to the excavation, surface surveys were carried out along the east side of the road - in combination with metal detecting surveys -, where several Roman finds (ceramic and metal objects) were collected.

In order to validate our data, we also carried out systematic field surveys on 7 March and 12 September 2019, whereby the locations of the finds were recorded by handheld GPS devices (Garmin 60 and Garmin 62 ). The primary goal was to clarify the full extent of the site. A $25 \mathrm{~m}$ wide $\mathrm{S}-\mathrm{N}$ oriented grid was applied 
Eszter Soós - Lajos Juhász - Hella Mag - Róbert Molnár • Rare Roman Finds from a Germanic (Quadi) Settlement

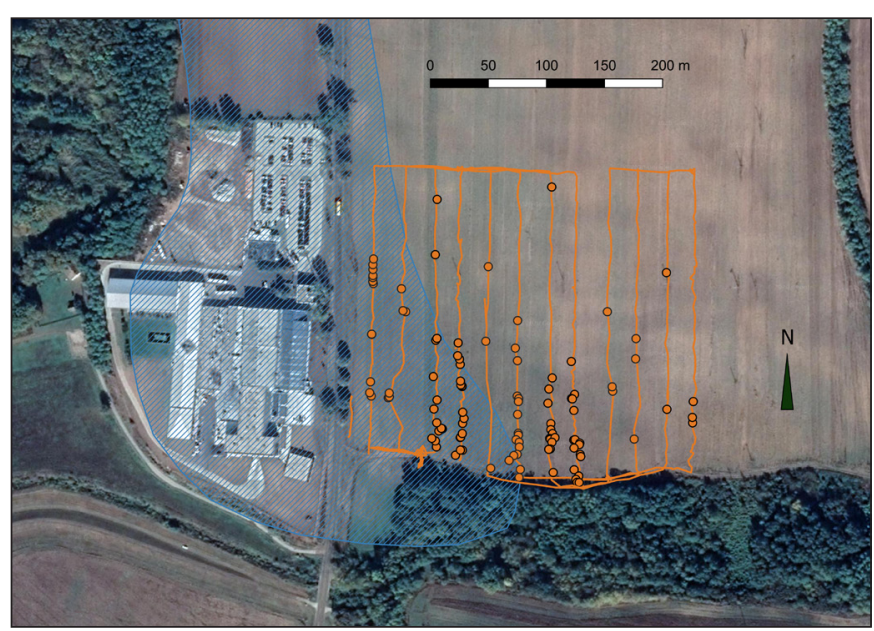

Fig. 3. The location of the Ipolytölgyes-TSz major site based on the distribution of ceramic finds collected 7th March, 2019

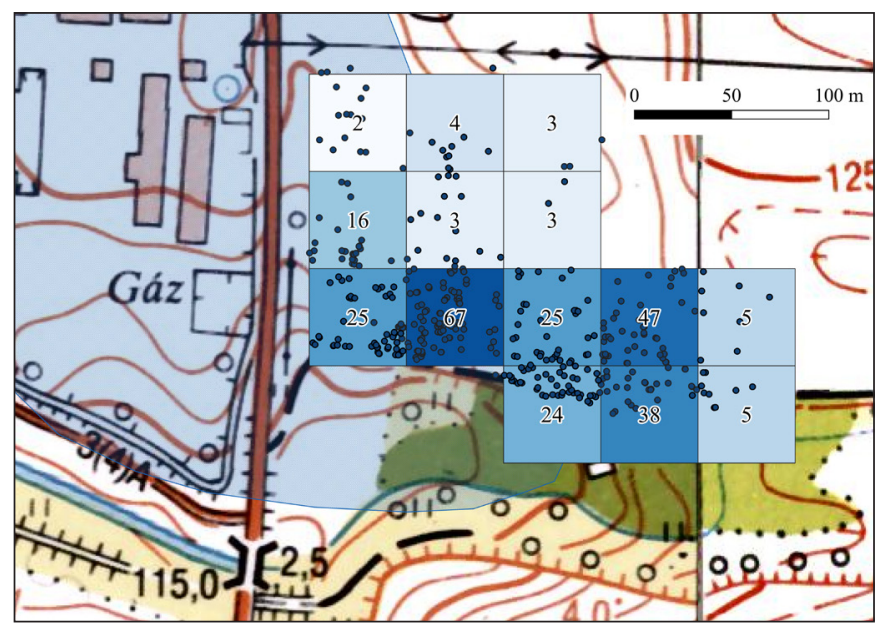

Fig. 5. The distribution of Bronze Age finds within the intensively surveyed area (number of fragments)

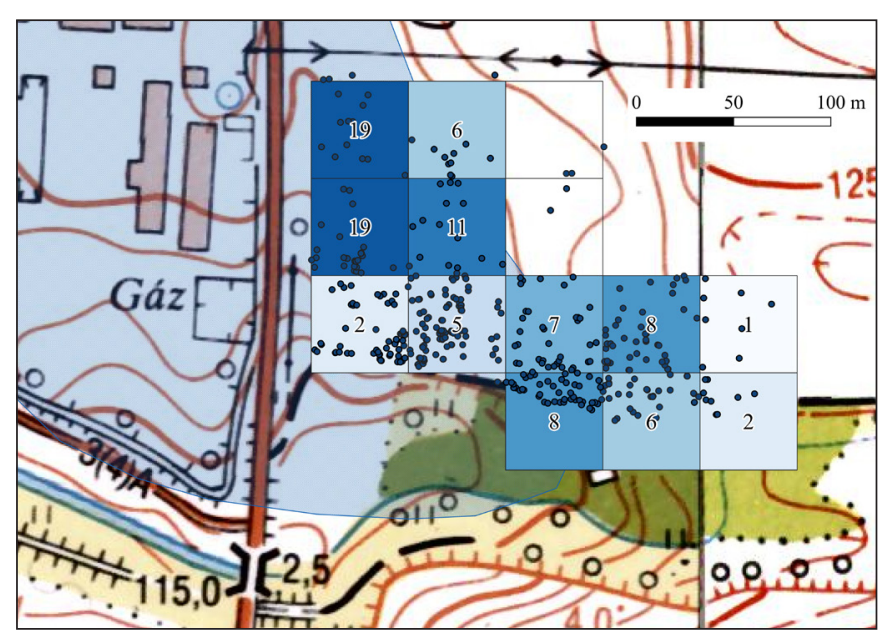

Fig. 4. The distribution of Neolithic finds within the intensively surveyed area (number of fragments)

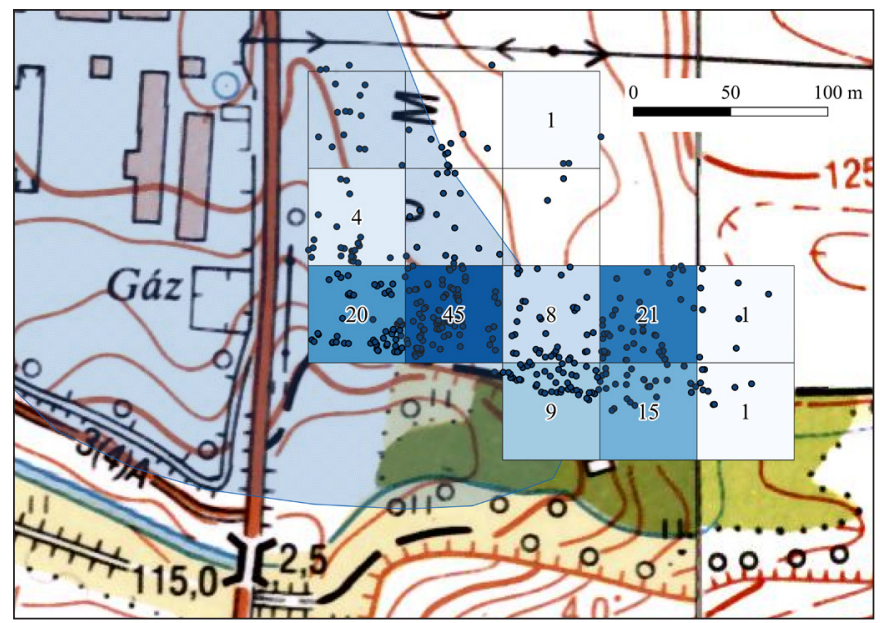

Fig. 6. The distribution of Roman period finds within the intensively surveyed area (number of fragments)

during the fieldwalking, and the locations of collected finds were recorded using $100 \mathrm{~m}$ grids. We did not lay out gridpegs on the surface, but only virtual grids $(50 \mathrm{~m}, 100 \mathrm{~m})$ were applied, using handheld GPS devices, based on EOV coordinates (the method is described in detail by MesterhÁzy, 2013). Projecting the survey area and the distribution of the finds on a map revealed that the site extends at least 70-100 $\mathrm{m}$ further to the east than previously suggested (Fig. 3).

Next, we carried out intensive surveys within the area where the occurrence of finds was the most frequent in order to determine exactly the archaeological periodization and the extent of the Roman settlement. For this investigation, we applied a $50 \mathrm{~m}$ grid, within which the exact position of each object was recorded before being collected and packed away together in each unit. Mapping the distribution of these finds, dating from different periods, it was possible to detect differences within a relatively small area. Neolithic sherds mostly occurred in the northern part of the area, along the driveway (Fig. 4). The spread of Late Bronze Age and Early Iron Age fragments rather followed the course of the Cserge Stream (Fig. 5). The traces of the Germanic, Roman period settlement were identified also along this stream, in a 50-100 meters distance from it (Fig. 6).

\section{RESULTS OF THE METAL-DETECTING SURVEY}

During the 2017 investigations, we were able to collect more metal objects from the site - fibulae, Roman coins - than was previously possible in other Quadi settlements altogether in Hungary. ${ }^{5}$ 


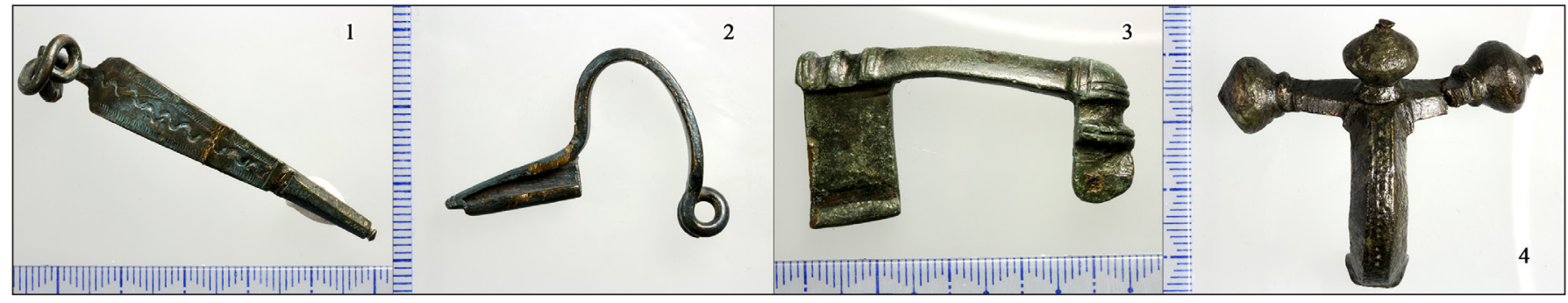

Fig. 7. Brooches collected during the metal detecting survey 1-2: Brooches with inverted feet, 3: Germanic knee brooch, 4: Fragment of a Roman brooch with onion-shaped knob (Photo: Edit Orlik)

Apart from a crossbow brooch (published in 1971) and an enamelled disc brooch (Exner III 24 type), there have been mostly one-piece brooches found in 2017-2019, with bent feet (inverted, or sideways), identified as Almgren VI type, dating from the 3rd century AD (Fig. 7/1-2). These simple types, with external chords, were widespread around the Germanic and Sarmatian territories. The exact analogies of some decorated pieces are known from Marcomannic-Quadi sites (VARSIK, 2011, 220, Abb. 102, 6).

Relatively rare types have also been found. Germanic knee brooches (Fig. 7/3) are generally associated with the period of the Marcomannic Wars and northern Germanic influences (MĄCZYŃSKA, 2001). Fragments of onion knob fibulae are of much later date - they represent a 4th century horizon (Fig. 7/4). Their occurrence in Germanic settlements is rare, but not unusual, however, their connection to Quadi settlement cannot be clarified at the moment.

The most distinguished finds at Ipolytölgyes were fragments of bronze objects, illustrating the lifestyle of a wealthier layer of Roman society (Fig. 8).

The terminal end of a solid cylindrical bronze handle decorated with incised lines was forming an animal head (possibly a feline). Despite the small size of the fragment, it could be identified as the fitting for a suspension ring of a deep, cylindrical

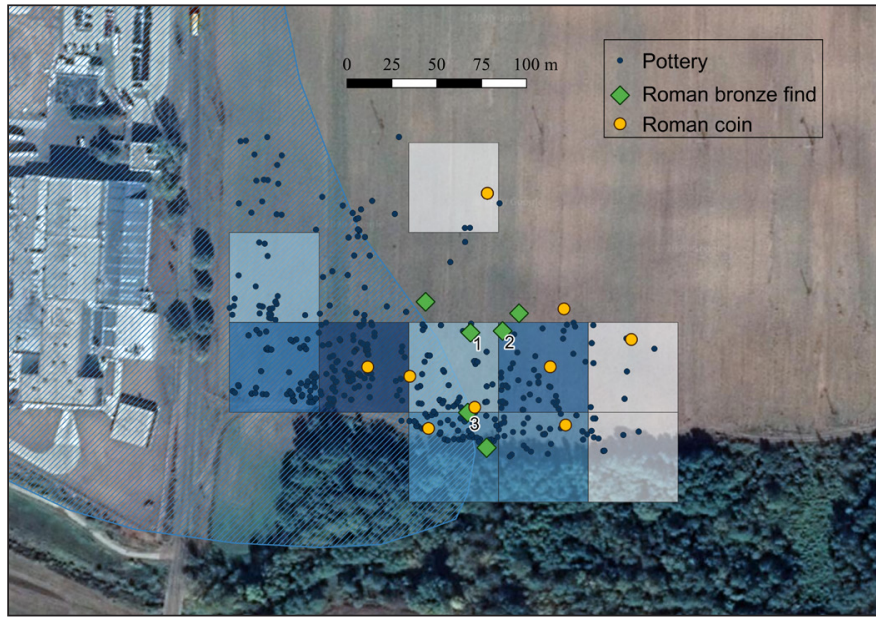

Fig. 8. The distribution of bronze finds and coins. 1: the bust of the tripus, 2: fragment of the bronze figurine, 3: fragment of the bronze vessel

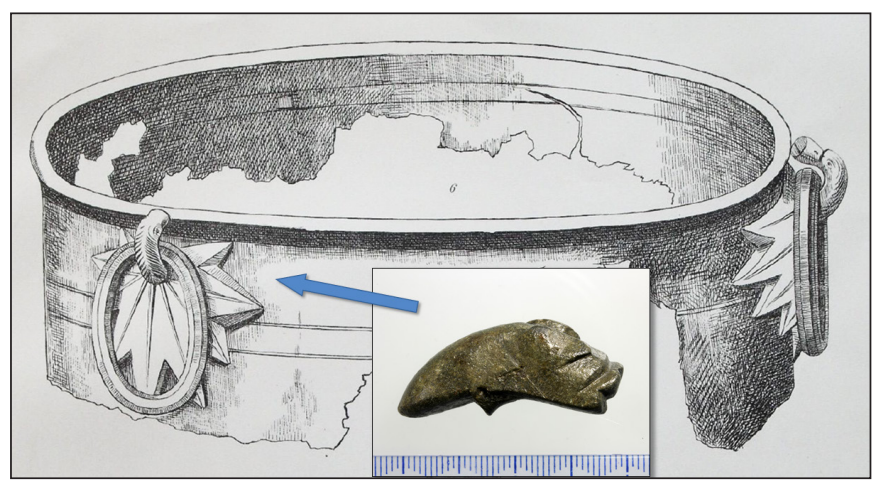

Fig. 9. Photo of the bronze vessel fragment from Ipolytölgyes and a drawing of the bowl found in Grave III in Sackrau (after Gempler, 1888, Taf. V, 6, photo: Edit Orlik). bronze bowl (Fig. 9). ${ }^{6}$ In the Danube province, this type was frequent in the first half of the 3rd century. They were used as washbowls, and examples are mostly known from settlements or depot assemblages (SEDlmayer, 2016, 383). In the Germanic Barbaricum, however, the type occurs primarily as grave accessory, in context of the wealthiest burials - i.e. the so called Leuna-Haßleben group, dating from the 3rd century, including e.g. the Sackrau I and III burials, and Grave II at Krakovany-Stráže (QuAst, 2009, Abb. 14, Abb. 26). During this period, Roman bronze vessels were particularly rare finds in Barbarian settlements. From Germanic settlements along the Danube there are altogether three fragments of Eggers 83 bowls known, as scatter finds (Iván \& ÖLveczki, 2012, 215, Fig. 9/7; SedlmaYer, 2016, 390).

6 Hereby, we would like to thank Jan Jílek (Masaryk University, Brno) for his assistance in identifying the piece. 


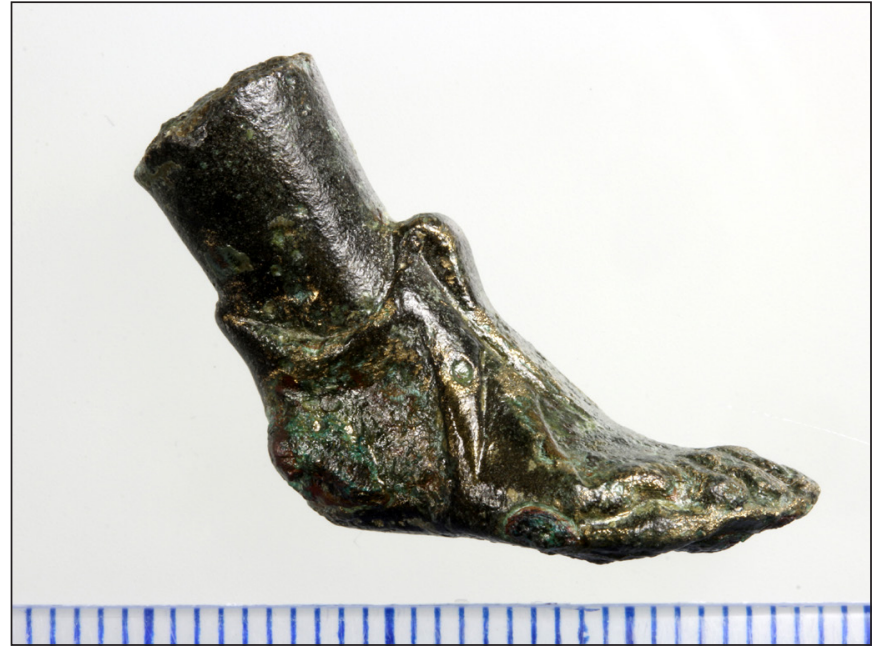

Fig. 10. Fragment of the Roman bronze figurine (Photo: Edit Orlik)

The fragment of a Roman bronze figurine bears the mark of a deliberate mutilation (Fig. 10). It is the foot of a figure, wearing a sandal, and it is slightly outstretched, as if the figure was standing on tiptoe. This posture can be mostly observed in case of Lar I type dancing figurines, holding a rhyton in their raised hands, and typically a situla or patera in their lowered hands (BARTUS, 2015, 77-78).

Our most impressive find is perhaps the sculpted ornament decorating the top of the leg of an adjustable bronze folding table (tripus). The $6 \mathrm{~cm}$ high and heavily worn bust probably depicts Attis wearing a Phrygian cap on his head (Fig. 11). During the early imperial period, folding tables with tripods or quadripods were used as altars of incense for presenting sacrifices. In the 3rd century, however, their function changed. As their production shifted from Italy to the provinces (including Pannonia), they became representative objects used by the provincial elites for showing their wealth and riches in their dining halls, or as washbowls (for the details see: KLATT, 1995). Due to their new function, their decorations often included Bacchic motives.

In the Barbaricum, examples of Roman tripods are known from 3rd-century burials, similarly to Eggers 83 type bowls, e.g. from Mušov, Krakovany-Stráže, Ostrovany or Gommern (QuAST, 2009, 17-19; BECKER, 2010). The tripods and the Eggers 83 bowls are connected by their original functions: this type of bowl (fitted with rings) could be hanged on the hooks of the busts decorating the tripods. Regarding the finds from the Barbaricum, however, it is not always possible to demonstrate that the two objects were used in sets. In Grave I at Sackrau, there was a quadripod (quadripus) found together with an Eggers 83 bowl, but the three rings of the bowl could not be fitted to the stand; in Grave II, there was only a bowl and no stand (Fig. 12) (Gempler, 1887, Taf. II-IV; 1888, Taf. V, 6).

In Germanic settlements, fragments of tripods are generally rare finds. Except for the Ipolytölgyes

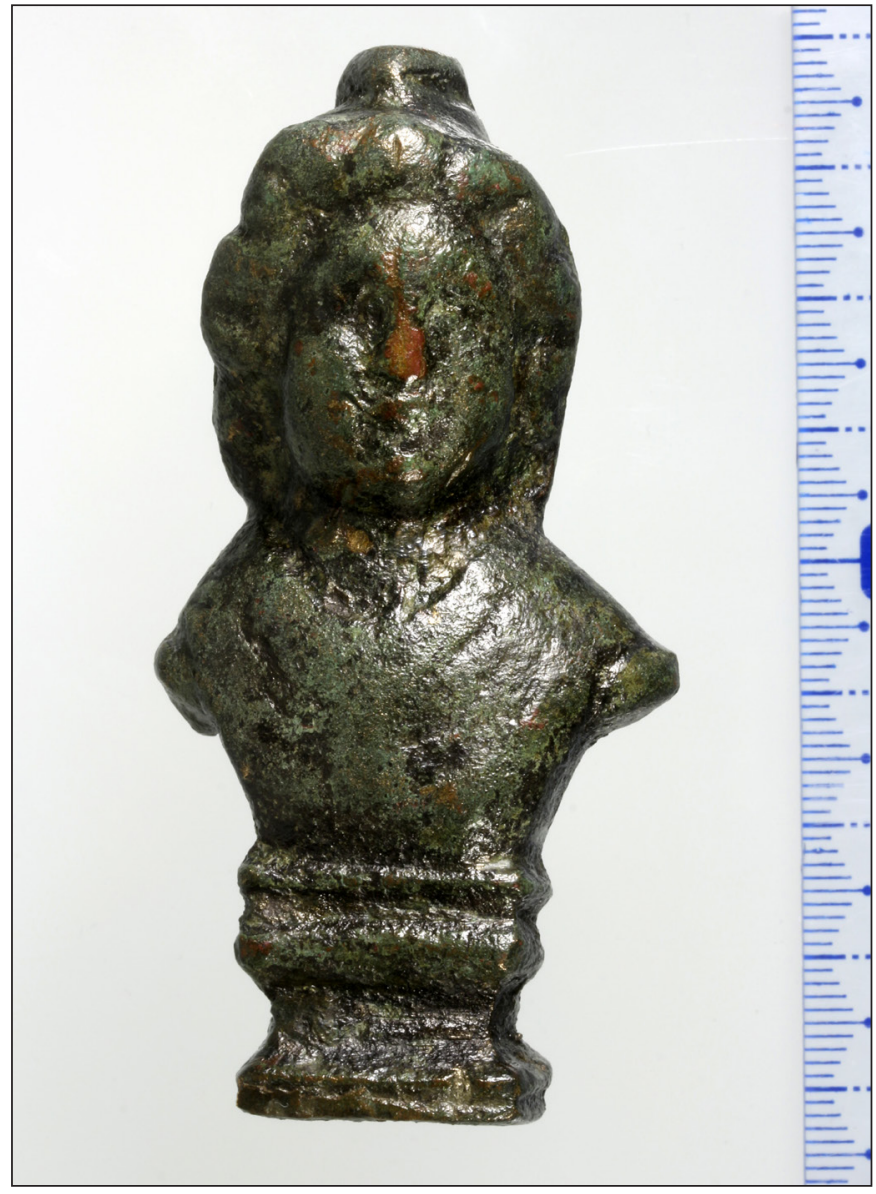

Fig. 11. The bust of the tripus from Ipolytölgyes-TSz-major (Photo: Edit Orlik)

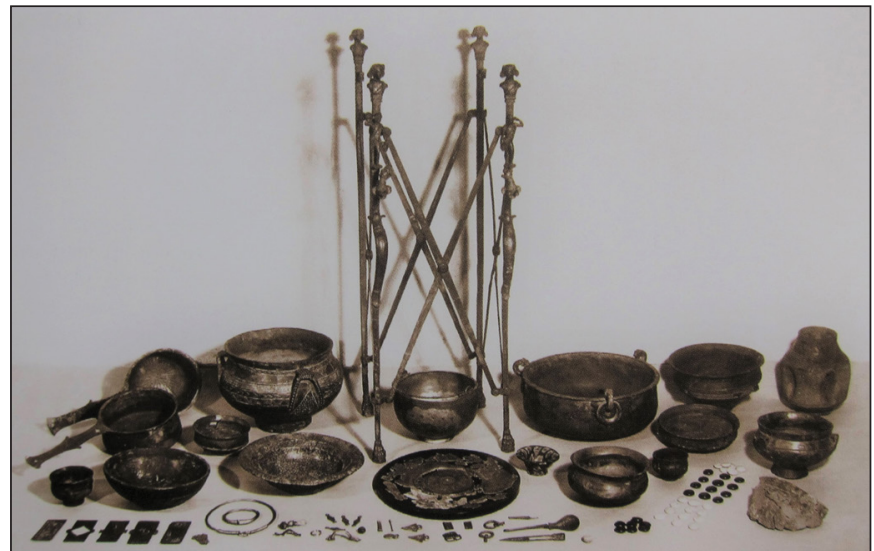

Fig. 12. Finds from Grave I in Sackrau (Quast, 2009, Abb. 14). 


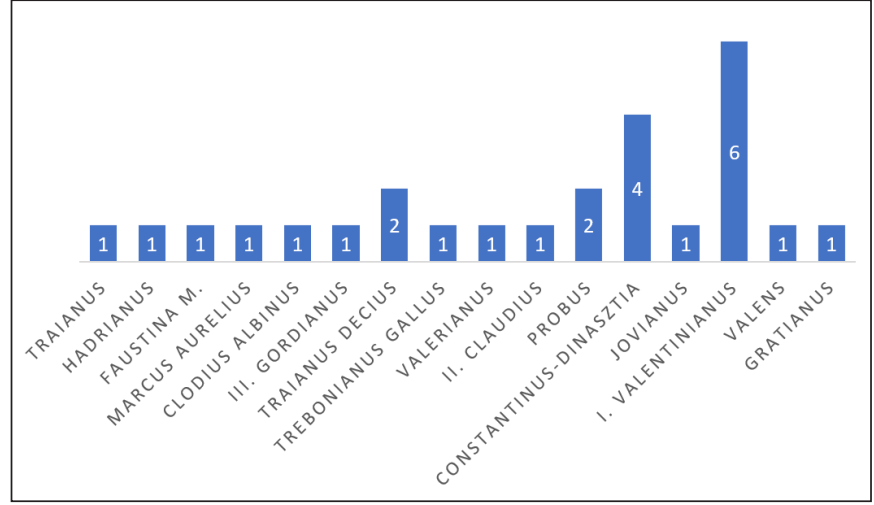

Fig. 13. The chronological distribution of the coins found in Ipolytölgyes

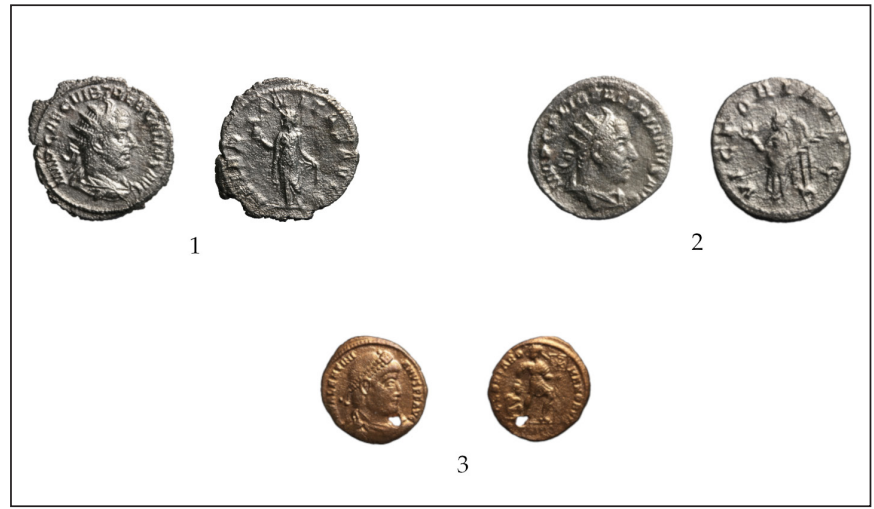

Fig. 14. Coins 1. Trebonianus Gallus, 2. Valerianus, 3. Valentinianus (Photo: Edit Orlik)

find, there is another piece known from Borsodszirák - possibly another Quadi settlement -, which also features a Bacchus bust (Тóтн, 2014, 161-162, Fig. 3, 1).

At Ipolytölgyes, altogether 33 coins were found during our research, dating from a 250-year-long period between the era of Trajan and that of the Valentinian Dynasty (Fig. 13).

Five coins are from the 2 nd century AD, including a rare denarius of Clodius Albinus. Eight coins are dated to the 3rd century, including an antoninianus of Trebonianus Gallus (Fig. 14/1), and another one of Valerian (Fig. 14/2). Four coins could be dated to the Constantine Dynasty, two of which date from 355-363 AD. The coin of Jovianus (Kr. u. 363-364), minted in Sirmium, is a rare find. The Valentinian Dynasty is represented by eight coins, which makes this period the most accentuated. ${ }^{7}$ Six coins belong to Valentinian I, one each to Valens and Gratianus, and four more can be only broadly dated to the 4th century. Three other coins were undatable. Regarding the types of the coins, there were 11 silver coins ( 3 denarii, 6 antoniniani and 2 aureliani). Among the smaller denominations 3 sestertii, 17 AE 3 and 2 AE 4 coins were uncovered. In addition to these, there were two antique counterfeits: a denarius subaeratus, and a sestertius limes falsa. As for the mints, nine coins were minted in Rome, eight were from Siscia, two from Viminacium, and one each from Sirmium and Cyzicus.

Interestingly, there are signs of secondary treatment on eleven coins. In case of six coins, at least one third of the flan was missing. In one case, only one quarter of the coin remained, the rest of it was accurately cut off. Similar finds could serve as raw material or could be used in local trade according to their weight and material (ELSCHEK, 2007, 146; JuHÁsz, 2017, 251-254). Five of the coins were pierced, ${ }^{8}$ and one of these was also mutilated. Coin finds from the neighbouring regions are currently under evaluation, which will allow a more in-depth analysis.

\section{SUMMARY}

As a result of the research in the past years, the site of Ipolytölgyes-Tsz-major became the most thoroughly analysed settlement of the Quadi along the Hungarian part of the Ipoly valley.

Materials recovered during the excavation date from the end of the 2nd century and the first half of the 3rd century; the metal finds and coins collected during the metal detecting survey can be dated to the 2nd-4th centuries.

Roman (provincial) vessel types included terra sigillata pieces from Westerndorf (GABLER, 1968, 230, 4. Abb. 4-6, GABLER \& VADAY, 1986, 17), fragments of Pannonian slipped ware bowls (PGW, Pannonische Glanztonwäre), red painted vessels, mortar bowl, indented beakers (Faltenbecher), and the fragments of a chalice decorated with applied threads - these were all common types in Quad settlements during the Severan era (Fig. 15) (VARSIK, 2011, 219, Abb. 100).

\footnotetext{
7 In case of another coin, with GLORIA ROMANORVM inscription on the verso, its dating to the Valentinian Dynasty or later, remains unclear.

8 Concerning the possible use or function of secondarily worked coins see JuHÁsz, 2019, 102-105.
} 
Eszter Soós - Lajos Juhász - Hella Mag - Róbert Molnár • Rare Roman Finds from a Germanic (Quadi) Settlement

Most of the ceramics were locally made, handshaped pieces. The tableware produced by local potters were black-fired polished vessels (bowls with inverted rims, saucers and pots) made of finegrained material (Fig. 15). Barbotine technique and meandering or combed wavy line band decorations were absent here, which is to be interpreted probably as a chronological phenomenon: $15 \mathrm{~km}$ from here, in Stúrovo there is another settlement post-dating the Marcomannic Wars, where richly decorated fine ceramics were documented (BELJAK, 2010, Obr. 12, 1-10, Obr. 22; VARSIK, 2011, 218, 222).

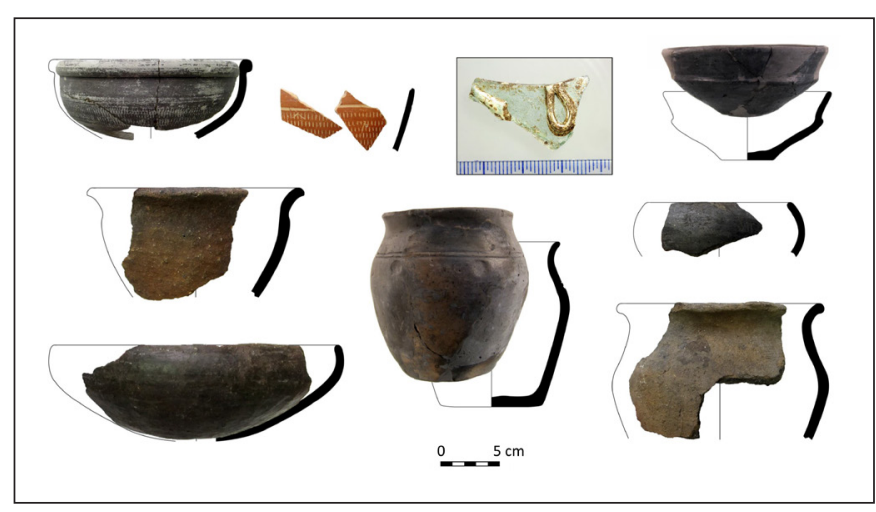

Fig. 15. Ipolytölgyes-TSz-major, roman import and local ceramic types (Photo: Edit Orlik, Eszter Soós)

The coins are not suitable for refined dating; however, the well-preserved coins of Trebonianus Gallus and Valerian indicate, by all means, a quick deposition, or at least a very short period of circulation. Noteworthy is also that a third of the coins were mutilated.

Among the finds, the fragments of the Eggers 83 type bronze vessel and the tripod are worth highlighting. Both types can be dated, in all probability, to the first half of the $3 \mathrm{rd}$ century, but one cannot rule out the possibility of a later deposition, in the 4th century. In case of settlements in the Barbaricum, and in this case only $15 \mathrm{~km}$ away from the Limes, their interpretation cannot be treated separately from chronological questions. Helga Sedlmayer suggested that the trade of Roman bronze vessels towards the Germanic territory could have stopped following the Marcomannic Wars (SEDLmaYer, 2016, 394). Consequently, it would be problematic to interpret these finds as trade goods; all the more, since these types did not typically become grave accessories, apart from the graves of the elite. Their functional use - due to their fragmentary nature - cannot be suggested either. They might have found their ways to Germanic possession as booty acquired during pillages in the province, then simply became dismantled and used as raw material in local production. Based on data discussed so far by international research, it seems likely that the presence of Roman bronze objects in the Germanic territories of the Barbaricum is to be explained not only by political contacts and their representative value (regardless their explicitly high value in their original context), but also by their use as raw material supplies (BECKER, 2003).

\section{BIBLIOGRAPHY}

Bartus, D. (2015). Bronzistenek. Rómaifigurális bronzplasztika Brigetióban [Bronze gods. Roman period bronze statuettes in Brigetio]. Acta Archaeologica Brigetionensia Ser. I. Vol. 8. Komárom: Klapka György Múzeum.

Becker, M. (2003). Klasse und Masse - Überlegungen zu römischem Sachgut im germanischen Milieu. Germania 81, 277-288.

Becker, M. (2010). Das Fürstengrab von Gommern. Veröffentlichungen des Landesamtes für Archäologie Sachsen Anhalt 63. Halle: Landesamt für Denkmalpflege und Archäologie Sachsen-Anhalt.

Beljak, J. (2010). Germánske osídlenie v Štúrove a na dolnom Pohroní v staršej dobe rímskej. Germanische Besiedlung im Štúrovo und unterem Gran-Gebiet in der älteren römischen Kaiserzeit. Zborník. Slovenského Národného Múzea C IV, 141-174.

Elschek, K. (2007). Römische Münzen entlang der Bernsteinstrasse im Slowakischen Marchgebiet nördlich von Carnuntum (Westslowakei) und ein Beleg der Sekundärvewendung von römischen Münzen. Slovenská Numizmatika 18, 143-156. 
Eszter Soós - Lajos Juhász - Hella Mag - Róbert Molnár • Rare Roman Finds from a Germanic (Quadi) Settlement

Erdélyi, I. \& Lamiová-Schmiedlova, M. (1971). Osada z doby rímskej v Ipolytölgyesi v Mad’arsku. Siedlung aus der römischen Zeit in Ipolytölgyes in Ungarn. Východoslovenský pravek 2, 51-72.

Gabler, D. (1968). Terra sigillaták a Kelet-Pannóniával szomszédos Barbaricumban. A Barbaricum importjának néhány kérdése. Sigillaten im Ostpannonien benachtbaren Barbaricum. Archeologiai Értesitö 95, 211-242.

Gabler, D. \& Vaday, A. (1986). Terra Sigillata im Barbaricum zwischen Pannonien und Dazien. Fontes Archaeologici Hungariae. Budapest: Akadémiai kiadó.

Gempler, W. (1887). Der Fund von Sackrau. Breslau: Museum schlesischer Altertümer.

Gempler, W. (1888). Der II. und III. Fund von Sackrau. Breslau: Museum schlesischer Altertümer.

Iván, R. \& Ölveczki, R. (2012). New Germanic settlement finds in the Western part of the Great Rye Island. In Sz. Bíró \& A. Molnár (eds.), Ländliche Siedlungen der römischen Kaiserzeit im mitterlen Donauraum (pp. 297-316). Györ: Mursella.

Juhász, L. (2017). Burning money - a coin hoard from Brigetio. Dissertationes Archaeologicae 3 (5), 251-258. http://dx.doi.org/10.17204/dissarch.2017.241

Juhász, L. (2019). Perforated Roman coins from the Aquincum-Graphisoft cemetery. In L. Juhász (ed.), Numismatica Pannonica I. Proceedings of the conference held by the Antique Numismatic Workshop on the 10th September 2018 at the Hungarian Numismatic Society Budapest, Hungary (pp. 91-110). Budapest: Hungarian Numismatic Society, Antique Numismatic Workshop. https://doi.org/10.37790/anhs.1.7

Klatt, U. (1995). Römische Klapptische. Drei- und vierbeinige Stützgestelle aus Bronze und Silber. Kölner Jahrbuch 28, 349-573.

Mączyńska, M. (2001). Einige Fibeln südlicher Herkunft im Hortfund von Łubiana in Pommern. In E. Istvánovits \& V. Kulcsár (eds.), International Connections of the Barbarians of the Carpathian Basin in the 1st-5th centuries A.D. Proceedings of the international conference held in 1999 in Aszód and Nyiregyháza (pp. 77-93). Aszód-Nyíregyháza: Osváth Gedeon Museum Foundation - Jósa András Museum.

Mesterházy, G. (2013). Regionális léptékü terepbejárás módszertani lehetőségeinek vizsgálata Magyarországon. Methodology and potentials of field surveys on a regional scale in Hungary. Archaeologiai Értesitö 138, 265-279. https://doi.org/10.1556/ArchErt.138.2013.10

MRT 9 = Dinnyés, I., Kővári, K., Kvassay, J., Miklós, Zs., Tettamanti, S. \& Torma, I. (1993). Pest Megye Régészeti Topográfiája [The archaeological topography of Hungary]. Vol. XIII/2. A szobi és a váci járás [The Vác and Szob region]. Budapest: Akadémiai Kiadó.

Quast, D. (2009). Wanderer zwischen den Welten. Die germanischen Prunkgräber von Stráže und Zakrzów. Begleitbuch zur Ausstellung im Römisch-Germanischen Zentralmuseum, 10. September 2009 bis 10. Januar 2010. Forschungen am Römisch-Germanischen Zentralmuseum Band 6. Mainz: Verlag des RömischGermanischen Zentralmuseums.

Rácz, T. Á. (2017). Metal detector users affiliated to museums: Building a model of community archaeology in Pest County. Hungarian Archaeology 6 (3) [2017 Autumn], 2-8. 
Eszter Soós - Lajos Juhász - Hella Mag - Róbert Molnár • Rare Roman Finds from a Germanic (Quadi) Settlement

Rácz, T. Á. (2019). Közösségi régészet. Egy új kutatási eljárás születése. Múzeumcafé: a múzeumok magazinja 13 (4), 149-157.

Sedlmayer, H. (2016). Die Spektren römischer Bronzegefässe in Noricum und dem angrenzenden Barbaricum im Vergleich - Typen des 2./3. Jahrhunderts n. Chr. In H.-U. Voß \& N. Müller-Scheeßel (eds.), Archäologie zwischen Römern und Barbaren. Zur Datierung und Verbreitung römischer Metallarbeiten des 2. und 3. Jahrhunderts n. Chr. im Reich und im Barbaricum - ausgewählte Beispiele (Gefäße, Fibeln, Bestandteile militärischer Ausrüstung, Kleingerät, Münzen) (pp. 379-397). Kolloquien zur Vor- und Frühgeschichte, Band 22/1. Bonn: Habelt.

Soós, E. \& Tankó, K. (2018). Late Roman Period Quad settlement at Pásztó-Csontfalva. In L. Borhy, K. Dévai \& K. Tankó (eds.), Celto - Gallo - Roman Studies of the MTA-ELTE Research Group for Interdisciplinary Archaeology (pp. 281-301). Paris: L'Harmattan.

Tóth, K. (2014). Noteworthy findings of the Roman Age and Early Migration Period from Borsodszirák, Northeastern Hungary. First investigations. A Herman Ottó Múzeum Évkönyve 53, 159-182.

Varsik, Vl. (2011). Germánske osidlenie na vŷchodnom predpolí Bratislavy. Sídliská z doby rímskej v Bratislave-Trnávke a v okoli [Germán település Pozsony keleti határában. Római kori települések Pozsony Trnávka kerületében]. Archaeologica Slovaca Monographiae - Fontes 18. Nitra: VEDA. 